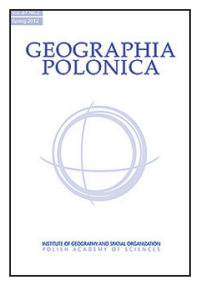

\title{
RURAL/URBAN: LAYING BARE THE CONTROVERSY
}

\section{Mirek Dymitrow}

\author{
University of Gothenburg \\ School of Business, Economics and Law \\ Department of Economy and Society - Unit for Human Geography \\ Viktoriagatan 13, 41125 Gothenburg: Sweden \\ email: mirek.dymitrow@gu.se \\ Chalmers University of Technology \\ Mistra Urban Futures \\ Läraregatan 3, 41296 Gothenburg: Sweden \\ email: mirek.dymitrow@chalmers.se
}

\begin{abstract}
Concepts are the basic building blocks of all knowledge, while the strength of any societal project is dependent on the quality of those concepts. As two of the oldest geographical concepts still in widespread use, 'rural/urban' stand in stark contrast to the immense changes encountered by the society over the last century, let alone decades. To better understand this controversy, this paper moves away from conventional rural and urban theory, and instead focuses on the philosophical constitution of this conceptual pair. By critically evaluating six of the most common conceptions of 'rural/urban', including their pros and cons, this paper makes a case for reconfiguring our relationship with familiar understandings of societal organization. The paper concludes that by paying greater attention to how concepts operate at a cognitive level, how they are construed and collectively maintained, can help facilitate decisions whether 'rural/urban' are truly analytically contributory to a specific line of thought or action, or whether they merely linger as a cultural ostinato that is too elusive to be conquered or held.
\end{abstract}

\section{Key words}

rural $\bullet$ urban $\cdot$ conceptions of space $\bullet$ critical analysis $\bullet$ knowledge production

\section{Introduction}

'Rural' and 'urban' are controversial concepts. In human geography, and in social sciences at large, they are increasingly recognized as problematic constructs rather than sets of geographically bounded facticities (Little 1999; Champion \& Hugo 2004; Halfa- cree 2006; Hubbard 2006; Cloke 2006; Scott et al. 2007; Woods 2011; Brenner 2013; Bosworth \& Somerville 2014; Dymitrow \& Halfacree 2018). As some of the oldest geographical concepts still around, their pervasiveness stands in stark contrast to the immense changes encountered by society over the last 
century, let alone decades. Steady, fast-paced transformations in the environmental, economic and social dimensions (cf. Rabbinge \& van Diepen 2000; Millward et al. 2003) have rendered 'rural/urban' decreasingly useful in the contemporary reality of interconnectedness (Hoggart 1990; Halfacree 1993; Pile 1999).

Specific morphologies, specific population densities or specific ways of doing economy no longer breed particular types of social relations, at least not to the point of granting them such primordial gravitas. As Cloke and Johnston (2005a) note, 'rural/urban' is one conceptual pair that "has survived the onslaught of material reality and philosophical re-positioning" (p. 10). Instead, "urban/ rural differences have carried with them other more hidden messages" that " [go] beyond the material look of the land and [imply] more deep-seated differences" (p. 11). Hence, although 'rural' and 'urban' today should perhaps best be understood as categories of thought (Mormont 1990), narratives (Ulied et al. 2010) or conversational realities (Halfacree 2009b), they continue to underpin and influence large sectors of societal organization as acceptable guiding perspectives (Ward \& Brown 2009; Brenner 2015; Tunström \& Smas 2017; Dymitrow et al. 2018). The point is that due to increasing blurring and the lack of definitions that work in practice (Somerville et al. 2014: 294), there is an ever greater likelihood that continued usage of 'rural/urban' in formal contexts (e.g., research, legislation, public administration, policy, land use, funding) may be ill-adapted to reflect a significantly changed society, and that unreflexive uses of these concepts may get in the way of making informed analyses and decisions.

As Bohleber et al. (2013: 501) argue, "[i]t is well known that there is a lack of consensus about how to decide between competing and sometimes mutually contradictory theories, and how to integrate divergent concepts and theories". By studying the concepts' history, phenomenology, construction, meaning-making and possibility of integration, it is pos- sible to understand the logic of their enactment. This is especially true for concepts with many, often fragmented and overlapping, meanings and implications. In that vein, the general aim of this paper is to critically evaluate the most common conceptions of 'rural/ urban' in order to help erase the contagion of indifference attached to them in a reality of recalcitrant admissibility. More specifically, this will be done by critically analyzing the problem of 'rural/urban thinking' from two perspectives: (1) the constancy of scholarly critique; and (2) philosophical repositionings. The first part aims to outline the problem from a reactionary perspective and the second part from a theoretical angle, within which six principal takes on 'rural/urban' will be presented and evaluated critically. Both tracks must be factored in to address the complexity of the rural/urban problem, and to systematically arrive at its appreciation. The article ends by sketching out a research gap, outlining a need to pay greater attention to 'rural/urban' as elusive concepts rather than as geographical spaces.

Due to this specific insistence, this article is not intended as a recapitulation of rural and urban theory. Instead, it provides a breakdown of the basic philosophical premises upon which most such theories rest. The merit of such an angle of approach is to weigh the pros and cons of each conception and, by laying bare the controversy within, help infuse more reflexivity into our everyday handling of 'rural/urban'.

\section{Methodological note}

In terms of orientation, this paper adopts both a systematizing and a critical take on the problem of rural/urban conceptualization by focusing on the concepts' constitution. Constitution, in this sense, denotes the various fundamental principles or established precedents according to which an entity is governed, which together make up (i.e., constitute) what the entity is thought to be. Conceptual constitution, hence, denotes all those signifiers put into a concept that produce 
intersubjective states of mind or representations of reality, associated with the name of that particular concept (Margolis \& Laurence 1999).

Assuming that a paper about a familiar geographical problem is unlikely to be poignant if confirming or disproving known assumptions, this paper engages with a redux-style interpretation of the phenomenon of rural/ urban thinking by restoring, remixing and remastering ideas from the existing research field. To do so, I work broadly - athwart different aspects, situations and contexts, and interdisciplinarily - across different theoretical frameworks from geographical, sociological, philosophical and psychological literature, with the overarching goal to provide a structured, repackaged case against unsolicited uses of 'rural/urban'.

In terms of format, this paper is crafted as a conceptual one. Conceptual research is nominally the opposite of empirical research, in that it seeks to undertake a logical clarification of a given phenomenon by combining theory with more general empirical insights and philosophical commitments (Maxwell 2013; Xin et al. 2013). Conceptual research assumes that knowledge is value-mediated and value-dependent (Guba \& Lincoln 1994) and therefore does not hold rigidly to a single set of assumptions. The reason for this is that concepts are never theoretically hermetic but build on multiple aspects of the noösphere (the sphere of human thought) and can be taken to represent a boundary-spanning conceptual nucleus (Hansen 2011). In line with the stipulation that conceptual research should seek to "avoid any methodological strait-jacketing and remain open and creative in [its] thinking" (Tribe \& Liburd 2016: 45), the here employed analytical framework is deliberately eclectically informed. Analytical eclecticism draws upon multiple theories to gain complementary insights into a subject and applies different theories in particular cases (Sil \& Katzenstein 2010). More specifically, this is done by combining historical deconstruction, situational analyses and abductive reasoning with various stylistic techniques (analogies, metaphors, similes) to articulate the (il)logic undergirding the deliberated conceptions.

In terms of conceptual research method, "expertise, long term engagement with the issues and deep knowledge of the relevant literature" is favored before systematic evaluation of empirical materials (Tribe \& Liburd 2016: 45). Mindful of this, Xin et al. (2013) propose "a process of scoping, comparison, reflection and abstraction [...] including defining concepts, comparing them, historical analysis, the construction of conceptual typologies, finding conceptual gaps, deep reflection, synthesizing and finally a reconceptualization of the subject" (summarized by Tribe \& Liburd 2016: 45). In that vein, while drawing on and combining insights from extensive empirical work, the methodological focus of this paper is on the philosophical analysis of the central findings common to much of the underlying empirical material. This includes divagations on how 'rural/urban' is produced, attained and withheld, and how it is used with regard to different, often contradictory, cultural meanings and significations.

\section{Constancy of critique}

'Rural' and 'urban' are powerful concepts that have been used to study and understand places for a long time. The rural/urban binary evokes powerful feelings and associations and "continues to have a material effect in shaping the social, economic and political geographies of large parts of the world" (Woods 2011: 49; see also Cloke \& Johnston 2005a; Meeus \& Gulinck 2008; Brenner 2011). It also remains "one of the oldest and most pervasive of geographical binaries" found throughout society and is deeply embedded in culture, science and planning (Woods 2011: 3). In effect, while 'rural' and 'urban' are becoming increasingly blurred in a wide spectrum of objective and subjective dimensions (Cloke 2006; Yeo \& Neo 2010; Easterlin et al. 2011; Woods 2011; Torre \& Wallet 2014), rural/urban conceptualization has remained a contentious way of understanding the world (Dymitrow \& Stenseke 2016). Interestingly, 
this lack of mainstreaming has found reflection in academic attitudes, whose longevity, persistence and similarity has accompanied 'rural/urban' for a long time.

Already a century ago, Galpin (1918) questioned the binary's validity, urging its immediate dissolution and replacement by a new orientation. Ever since, 'rural' and 'urban' have been characterized as "vague and contradictory and [whose] use should be discontinued for scientific work" (Galpin et al. 1918), while the "scientific justification for employing [them] has been described as entertaining" (Gillette 1917: 184). Questions pertaining to the continued legitimacy of 'rural' and 'urban' have been raised with regard to where to draw the line between them, deeming such practice "very uncertain, and even whether it is really worthwhile drawing it at all" (Bailey 1924: 162). The rural/urban distinction has been pegged as "not one of social networks or of institutional profiles but of individual outlook" (Stewart Jr 1958: 158), "reveal[ing] a gross lack of agreement concerning their referents" (Dewey 1960: 60). Being such a "fuzzy, descriptive designation", the matter 'rural' and 'urban' purport to depict "becomes relatively unimportant" (Bealer et al. 1965: 257). In turn, the terms themselves have become "more remarkable for their ability to confuse than for their power to illuminate" (Pahl 1966: 299).

It is not merely a matter of confusion though. The rural/urban binary has been characterized as a "rhetorical device", with us being "the victims of our own terminological duplicity" (Copp 1972: 159). For instance, the "theoretical crisis of rurality" has been found to lie in the "basic insufficiency of the sociological concepts with which rural phenomena have been apprehended" (Galjart 1973: 254-5), leading to "a form of theoreticalempirical myopia influencing what is known and can be known about [...] the concept 'rural'” (Falk \& Pinhey 1978: 547). Sher (1977: 1) went even further, claiming that "rural people, rural communities, and rural conditions are so diverse that we can find evidence to support nearly any characterization".
By the 1980s, the time felt ripe for some conclusions. Newby (1986: 209) conceded that "[t]here is now, surely, a general awareness that what constitutes 'rural' is wholly a matter of convenience and that arid abstract definitional exercises are of little utility". In the same vein, Hoggart (1990: 245-6) observed that "the designation 'rural', no matter how defined, does not provide an appropriate abstraction [...] [and if] we cannot agree what 'rural' is, this does not give us carte blanche to rely on 'convenient' definitions of it". Also, the concept 'urban' has been met with similar critique, with Thrift (1993: 229) identifying "something of an impasse" in urban studies, replete with "recycled critiques, endlessly circulating the same messages".

Well into the 2000s, little had changed. As Cloke (2006: 20) observed, "[d]espite strong warnings to the contrary [...] these loose concepts continue to underpin aspects of rural studies [...with...] empirical work conducted on this basis [often being] flawed". According to Cloke and Johnston (2005a: 11), "the rural/urban divide has been kept alive by a binary model of thinking, peddling ideas of separation, difference and even opposition", while in practice "the divide has become blurred in all kinds of ways". This blurring has made any rural/urban distinction increasingly "irrelevant", to the extent it is "no longer useful for making sense of societies characterized by high levels of geographic and social mobility" (Hubbard 2006: 2). The severity of this continuation led to geographers extending their concerns to notions of ideology, normativity and even myth-making (Eriksson 2010; Nilsson \& Lundgren 2015). As Halfacree (2009b: 450) put it, "continued belief in any town versus countryside divide may even be seen as ideological, both denying and confusing human understanding of the spatiality of contemporary capitalism" (cf. also Brenner \& Theodore 2002), while Stenbacka (2011: 243) pondered whether "the divide [is] used to underpin the struggle to constitute the superior and uphold a prevailing norm".

As the above outline suggests, 'rural/ urban' can be conceptualized very different- 
ly, with each conceptualization being equally problematic, for example: "Functional and political-economy conceptualizations of rurality have struggled to resolve this paradox", leading to the suggestion that the 'rural' should be abandoned as an analytical term [...] whilst social constructionist approaches have focused on the discursive realm to the neglect of actually existing social and economic relations" (Woods 2011: 43).

Effectively, the variety of functions and meanings attached to the rural/urban binary has made it "an ambiguous and complex concept" and "a messy and slippery idea that eludes easy definition and demarcation" (Woods 2011: 1)². Consequently, trying conclusively to define it materially "runs the risk of perpetuating a 'chaotic conception' [...] of space that is most unlikely to ground a robust [...] structured coherence" (Somerville et al. 2014: 282). This means that 'rural' and 'urban' have come to a point in their conceptual development at which they can signify almost anything (Sher 1977; Hoggart 1990; Cloke 2006; Woods 2011) and this span widens with an ever-greater speed without raising considerable intellectual doubts ${ }^{3}$.

\footnotetext{
1 Woods (2011: 43) refers to the fact that "the networks and flows of people and goods, capital and power - have always transgressed the discursive divide of urban and rural".

2 It should be noted that, from a cognitive point of view, meaning and utility are two different things that should not be used interchangeably to claim scientific merit. The conflation of meaning with utility is a very common point of misunderstanding in scholarship (and policy) that has rendered a false sense of stability, in which 'rural/urban' are not perceived as problematic as they probably should (Dymitrow \& Brauer 2018: 199-200).

3 A recent example from Poland involves Wiślica, a tiny rural settlement of 500 inhabitants, which was granted urban status on 1 January 2018 as the result of a change in political discourse. By invocations to past injustice (Wiślica had urban status in the past and lost it during the reign of an oppressor), nationalistic sentiments were allowed to lower the hitherto accepted demographic minimum heuristic for urbanity in Poland (c. 2000 inhabitants) by 75\%. More recently still, the even smaller village of Opatowiec (population just above 300) is predestined to be rendered 'urban' on 1 January 2019 for similar reasons, placing it in the same "urban basket" as Warsaw. Contrarily, large and
}

This dual attitude - condoning a rural/ urban distinction on the one hand yet criticizing it on the other - has necessitated new ways of philosophical repositioning to accommodate this disparity. Perhaps more interestingly, the constant repositionings point to a collective preference for "salvaging a sinking boat" rather than discarding it. With this in mind, my point of departure is that the challenge to understand 'rural/urban' today lies not in determining what 'rural' and 'urban' are, but in what way something or someone is considered 'rural' or 'urban' and why. This also means that while my analysis builds mainly on insights from "Western" literature, as an assessment of how rural/ urban conceptions are construed on a philosophical level the analyzed models of binary thinking are socio-culturally acentric. The proposed analysis also eschews evaluation of rationality of any one model within specific geographical contexts, acknowledging that some models may be more applicable than others in different parts of the world. In the next section, some of the most popular conceptualizations of 'rural/urban' will be presented, accompanied by a critique of those conceptualizations.

\section{Philosophical repositionings}

From the preceding overview we can surmise that 'rural' and 'urban' are vague concepts fueled by discourses from various epochs, standpoints and interests. The city and the countryside are ambiguous subsystems of meaning because of their dual function in the socio-economic macrosystem: complementary and contradictory at the same time (Stanny et al. 2017). While this ambiguity

\footnotetext{
fully urbanized 'rural' settlements like Kozy, Koziebrody or Pawłowice refrain from applying for urban status for pragmatic reasons, namely to retain their eligibility for a number of rural-earmarked subsidies, like those aimed at teachers and farmers. By tolerating conceptual manipulation for various secondary gains (be it prestige, revenge or economic gains), the primordial value of the rural/urban distinction is stretched to the maximum, virtually depleting it of its semiotic potential (Dymitrow 2013; 2017a; 2017b).
} 
poses an insoluble methodological dilemma, researchers still continue to look for differences between them. The aim of the following review is to summarize how 'rural' and 'urban' are most often handled in practice at a conceptual level, but also to outline some general problems associated with such conceptualizations.

For the purpose of this overview, I depart from the most common conceptions of rural/ urban in social sciences: dichotomy, continuum, hybridities, relationalities, performativities and networks ${ }^{4}$ (Fig. 1). It should be noted though that within each conception I treat 'rural/urban' as a binary, i.e. as a simple, socially constructed, amalgamation of two elements within the wider human activity of categorization (Cloke \& Johnston 2005b). This means that while 'rural/urban' can be approached independently of each other (What is 'rural'? What is 'urban'?) or in tandem (In what way is 'rural' different from 'urban'?), maintaining a binary perspective is philosophically necessary to stabilize the points of reference, but also historically and geographically substantive. Moreover, given the conceptual focus of this paper, I am here less concerned with what these concepts mean (in isolation they can mean virtually anything), but rather how they are construed and played off against each other at a conceptual level. The calibration of that level, in turn, is always determined by fleeting discursive developments, ultimately affecting our understanding of 'rural/urban'.

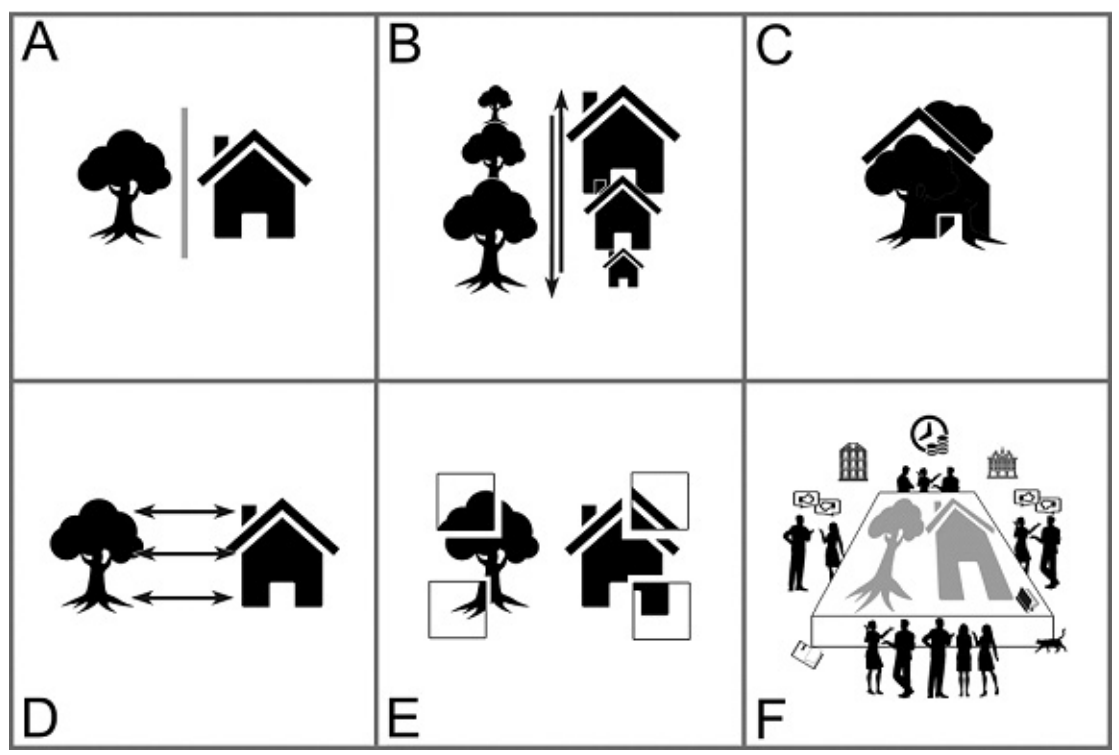

Figure 1. Graphical representation of the deliberated conceptions of 'rural/urban': (A) as a dichotomy; (B) as a continuum; (C) as hybridities; (D) as relationalities; (E) as performativities; (F) as networks

Source: Author's reinterpretation.

\footnotetext{
4 There are also other, less frequent, strands, ranging from 'forces' on the one end (in the physicalistic/ mechanicistic tradition) (Colby 1933; recently e.g. Krzysztofik 2016; Krzysztofik et al. 2016, 2017) to 'affects' on the other end (in the non-representational tradition) (Thrift 2007; cf. Halfacree 2009b; Dymitrow 2013).
}

\section{'Rural/urban' as a dichotomy}

Binaries often assume the qualities of either dualisms or dichotomies. Dualisms (also known as dualities) are integrative and mutually sup- 
porting. They constitute a system of meaning of two essential and irreducible parts or a philosophical construct of two equal, interplaying forces (think of yin and yang). While opposite in meaning, they are not necessarily based on valuation but on complementarity (none is better or worse). Dichotomies, contrarily, represent a division of a given totality (by means of conscious processes) or a contrast between two things as being opposed or entirely different. To be considered a dichotomy, the two parts must be jointly exhaustive (everything must belong to one part or the other) and mutually exclusive (nothing can belong simultaneously to both parts). As such, dichotomies are largely disintegrative, rarely symmetrical and likely to be polarizing. The process of treating continuous or multicategorical variables in a two-part fashion is called dichotomization, wherein the discretization error is ignored for the purposes of convenience (Hoggart 1990; Freibach-Heifetz \& Stopler 2008). Dichotomies (especially visible in gender) have been described as a social boundary that discourages from crossing or mixing assumed roles and viewpoints, or from identifying with three or more forms of expression altogether (Pile 1994).

A common way of representing the rural/ urban binary (in scholarly literature, in policy and planning, and in lay speech alike) is as a dichotomy: if something is 'rural', it is not 'urban' (and vice versa). As Stanny et al. (2017) observe, this view is historically (rather than theoretically) conditioned, additionally strengthened by the geographical (and, before it, sociological) research tradition. This led to the establishment of certain theoretical regularities, which, due to the high level of abstraction involved, found little common ground with the realities they purported to portray.

There are several problems with dichotomies. One of the most salient characterizations of 'rural/urban' is that of between descriptive and socio-cultural definitions. Descriptive definitions (Cloke 1977) accept that 'rural' and 'urban' exist, whereby 'rural' and 'urban' areas are identified through the "correct" selection of parameters that define their socio-spatial characteristics (e.g., agricultural, morphological, demographic). Sociocultural definitions (Tönnies 1887 [1957]; Wirth 1938), on the other hand, highlight the extent to which people's socio-cultural characteristics vary with the type of environment in which they live (e.g., that population density affects certain behaviors and attitudes). Both approaches, however, besides not working well empirically, have since been criticized for being theoretically flawed: socio-cultural definitions as spatially deterministic, while descriptive definitions as spatially indifferent and hence ontologically shallow (see Halfacree 1993 for an overview). Since both approaches "demonstrate an erroneous conceptualization between space and society" (Halfacree 1993: 26), the problem lies less in how they are conceptualized and more in how these two supposedly different kinds of space are opposed to each other by way of dichotomization.

It is easy to think in dichotomies, especially since dualistic thinking is a psychological predisposition of humanity (Buss 2015). Moreover, this need for differentiation is not done randomly, but along certain semantic watersheds, which, logically, reflect the intellectual spur of time in terms of constructed relations. According to Derrida (1981: 41), for instance, meaning in the West has been defined strictly in terms of binary oppositions to form "a violent hierarchy" with "one of the two terms governing the other". The first term in the binary is "endowed with positivity at the expense of the other: presence and value are attached to factory, while nonfactory is absent and devalued" (Gibson-Graham 2000: 97-98). In other words, there is a universal, culturally and psychologically sustained proneness to dichotomize concepts, even those we objectively know to be nondichotomous (e.g. colors, cf. Özgen 2004).

Clearly, the rural/urban divide is not an exception (Cloke \& Johnston 2005b). 'Rural/urban', despite a plethora of literature deliberating their changed semantics and significance, are still conceptually rooted 
in a dichotomy: if something is not 'urban' it is 'rural' (and vice versa), regardless of where we choose to place the separator today. In effect, what we get is a myriad of contextbound separators operating under a common conceptual banner (Cloke 2006), a situation that creates a false sense of stability (Rey 1983). Brenner (2015) demonstrates this through his account of "urban theory", which he considers today to be "in somewhat paradoxical condition". On the one hand, there is massive disagreement within the field about almost anything: what 'the urban' is, what methods should be used to study it, and so on. On the other hand, the field is very strongly marked by the legacies of the last 100 years, presupposing certain underlying spatial taxonomies derived from the period of capitalist development in which the field emerged. Hence, the urban/rural divide represents two specific types of space that supposedly should be studied according to their own particular principles, and this, Brenner concludes, continues to be "epistemologically constitutive for thought and action in relation to urban questions" (Brenner 2015).

Because of that pervasiveness, and owing to a process known as internalization of reality (Berger \& Luckmann 1966: 129-62), 'rural/ urban' have given rise to separate theories and separate professional paraphernalia, including books, scientific journals, conferences, scholarships, education programs, and departments, all named eponymously after these old spatial categories. And while 'rural' and 'urban' no longer represent discrete physical environments or particular lifestyles, their extant institutional materialities inevitably force researchers and professionals to operate within their particular conceptual boundaries, keeping the dichotomy afloat (Gieryn 1983).

Although we are witnessing efforts to revert the view of 'rural/urban' as a dichotomy and make it more similar to a dualism (with the countryside and the city being remodeled into "linkages" and "relational" systems), it is mostly a philosophical exercise. If a construction is no longer supported by soci- etal structures, trying to transform it into the binary's less disruptive cousin (the dualism) could be seen as futile at best or irresponsible at worst.

As Stanny et al. (2017:276) outline, "[d]rawing the line between the city and the countryside is arbitrary and will always raise doubts. However, the unequivocal adoption of specific criteria gives rise to enormous consequences and puts weight on how an area will be developed [emphasis added]".

We must not forget about these consequences when dealing with 'rural/urban' in a dichotomous fashion, as preconceptions informed by amalgamations of the rather dated and naive social theories underpinning such a model are very likely to impinge negatively on, for example, research outcomes, governance solutions and policy formulation (Champion \& Hugo 2004; Scott et al. 2007; Lerner \& Eakin 2011).

\section{'Rural/urban' as a continuum}

Out of efforts to subdue the impact of dichotomous formulations of 'rural/urban', the concept of rural-urban continuum arose as a response to the increased modernization in the late 19th century brought about by the industrialization and urbanization ( $\mathrm{Hal}$ facree 2009a: 119). Influential to this development was Tönnies's work [1887] (1957), which, although still approaching the problem dichotomously, managed to reverse the hitherto positive connotations ascribed to the cities and the pejorative view of rurality as captured in Marx's famous expression: "the idiocy of rural life".

Thinking in terms of continua (gradients) is a tempting and potentially effective way of reducing the harshness of dichotomies. This is perhaps best illustrated with colors, which naturally form a spectrum of various wavelengths, often unperceivable when confronted with one specific color. In the same manner, the idea of a rural-urban continuum assumes that 'rural' and 'urban' exist, but the transition between them is not abrupt, but smooth and gradual (e.g., remote village - 
developed village - town - city - metropolis) (Dewey 1960). The rural-urban continuum should thus be understood as a group of settlements occupying the middle part of a rurality-urbanity scale, where rural and urban units are interspersed (Kirk 1980).

While the concept of rural-urban continuum added a different dimension in terms of flexibility, it has not passed unscathed. A pioneering and highly influential critique was raised by Pahl (1966), whose attempts to read off social patterns (ways of life) from spatial milieus had failed and which he deemed worthless. In summary, the continuum idea - as opposed to the rigid rural/urban dichotomy - is seemingly more nuanced but obfuscates a number of important issues (after Halfacree 2009a). Firstly, there is very little evidence of space and society mutually reinforcing each other to the degree that the continuum idea could be a valid representation of reality. Secondly, the concept obscures the heterogeneity of urban places (at the one pole) and downplays the lacking reference to typical rural places (at the other pole), which instead are made by implication. Since the "purely urban" and "purely rural" are merely abstractions of the dichotomy, devising a gradation upon something that does not exist (or cannot be grasped epistemologically) renders the continuum idea a mental exercise. The idea also fails to empirically account for the lack of de facto gradation with regard to physical proximity (e.g., from the city core outwards), while conceptually it has been criticized for environmental determinism, a priori self-containment and inverted ethnocentrism (privileging "Western" perceptions, cf. Siwale 2014).

To further clarify the problem with the continuum idea, let me illustrate it with a reference to gender. Firstly, contemporary gender theory does not consider gender as merely biological sex, but also includes four other psychosocial aspects, including gender identity, gender expression, sexual attraction, and romantic attraction. Secondly, and more importantly for the sake of our analysis, not only are those aspects non-binary, but each aspect represents a separate slider onto which each and every individual's genderrelated inclinations can be mapped. This way of mapping gender, hence, is not monoaxial (with one single male-to-female axis) but generates an uncountable range of combinations (where each of the five sliders has its own, independently set, male-to-female axis), somewhat similar to that of a padlock code (Killermann 2013). ${ }^{5}$ Now if the values on the five sliders are staggered (not aligned), it is very difficult to determine one's gender proclivity using variations on the male/female binary ${ }^{6}$.

The same model of thought applies to the rural/urban continuum model, but here instead of five sliders there are many more. Having reviewed an extensive body of theoretical work dedicated to rural/urban conceptualization, Dewey (1960) identified more than 40 attributes usually associated with urbanity, whereof at least 10 find very frequent usage (Pile 1999; Sokołowski 1999). Consequently, since urbanization is an irregular process, each of these attributes (sliders) is likely to be configured differently. For instance, in de-agrarizing and mobile societies of information and communication technology, differences in lifestyle are becoming less pronounced. Today, thence, many geographical areas can be at the same time 'rural' and 'urban'7 or neither (Dymitrow \& Stenseke 2016). For instance, a settlement can be $100 \%$ 'non-rural' in terms of non-agricultural employment (the functional attribute), but this does not make it automatically

\footnotetext{
${ }^{5}$ It should be noted that this point of view has since been criticized by some contemporary psychologists, arguing that what comes to define gender is conditioned by both biological and cultural factors (e.g., Baron et al. 2015), and that for the most people the sliders are reasonably aligned.

${ }^{6}$ Consequently, in pace with the growing popularity of the identity politics discourse, the trend today is to expand the gender conceptology to be more inclusive (Facebook, for instance, had, in 2017, 71 gender options).

7 A caveat: I am not at ease using such descriptions, and why I do it here is merely for pedagogical reasons, departing from the theory of rural-urban continuum.
} 
'urban' with regard to, for instance, density and scale. On the other hand, a settlement can be $100 \%$ 'urban(ized)' in terms of infrastructure (e.g., the extent of water, sewage and gas supply, transport provision and digitalization), but at the same time remain 100\% 'rural' in terms of centrality (lacking supralocal facilities altogether like banks, theatres and law firms) (Sokołowski 2015). This means that when investigating, for instance, 'rural' and 'urban' people's lifestyles it seems unwarranted to take into account a classification of rural and urban areas based on function (e.g., intensity of agriculture) or density (number of meters between buildings). This would be like mixing apples with pears.

Since the problem of the wide range of rural/urban variations is impossible to account for in practice, continuum enthusiasts usually adopt an aggregated approach (Sokołowski 1999). In other words, to forcedly place scattered data on a monoaxial continuum, we must resort to artificial mean values (Dahly \& Adair 2007). This, in turn, is a very meager representation of what the conceptual model (continuum) is trying to depict. Think of this via the analogy of assessment sports - like figure skating or dancesport and how they are judged. If all adjudicators award the same couples with more or less the same points (placements), then their relative placements in the competition can be said to align with the actual (technical, athletic and musical) achievements of those couples. Such an outcome is then considered fair by minimizing the interference of subjectivity and maximizing objectivity (in line with the strictly regulated standards of how certain types of performance should be awarded points). Contrarily, a competition scoreboard marred by scattering and lack of consistency between the different adjudicators do not produce satisfactory results. The couples are of course given placements (by way of advanced mathematical algorithms), but the results produced in this way are accepted more as a necessity of the competition format (it must produce ranking) rather than a fair reflection of reality. The difference between assessment sports and rural/urban, however, is that life is not a competition, and arithmetical approaches to scientifically "adjudicate" rurality/urbanity according to the continuum principle are - at least from a social-science perspective - inappropriate.

This brings us to the important question: what is really the purpose of the continuum idea? Why would we want to know that a municipality is, say, "63\% urban", and how should we interpret it? Notwithstanding the fact that different "63\%-urban" localities can be diametrically different due to the countless possibilities of internal combinations on the rural-to-urban axis (vertical variability), the added nuance ("63\% urban") will eventually be lost as long as we continue to organize society in a dichotomous fashion (i.e., if the policies, research orientations, administrative divisions, fund designations, salary levels, etc. continue to be 'rural' or 'urban'). Also, thinking in terms of horizontal variability (comparisons between differently aggregated urbanities that produce the same arithmetical values) is treacherous in that a "63\%-urban" settlement may have nothing in common with either the model city (at the one pole) or with the model village (at the other). In conclusion, the continuum idea has become too complex to be qualified or quantified, signaling a need for a different kind of philosophy.

\section{'Rural/urban' as hybridities}

Although the rural-urban continuum is a meager heuristic tool, empirical evidence continues to support its apparent significance in certain circumstances (Halfacree 2009b: 123). Still, realization that actual social and economic relations (flows of people, goods, capital, and power) "have always transgressed the discursive divide of urban and rural" (Woods 2011: 43) has given way for more creative conceptualizations of the both concepts. The third way of viewing 'rural/ urban', as hybridities, represents one such development.

A hybrid is the result of combining or crossbreeding two or more parts, which 
means that the result is something different than those constitutive parts. The practice of stitching together what never should have been divided in the first place has an established niche in scholarly philosophical literature. Lefebvre (1962) [2011] displaced the conventional divisions between 'modern' and 'unmodern' by moving from philosophy to sociology enmeshed in the social, political and cultural forces at work in post-WW2 France, setting up in this way the path toward postmodernity. Berman (1983) examined the conflicting relationship between the concept of modernism and the processes of socio-economic development ('modernization'). Using various classical texts as a source of literary interpretation of modernization, Berman explored the self-destructive nature of modernization, arguing that modernity's defining characteristic is "that of continual reassertion of ambivalence". For Latour (1993), the dualistic distinction between nature and society inherent in modernity is an artificial construct and to make sense of it, Latour seeks to recouple the division. To do so, he proposes a "Parliament of Things" (Latour 1993), wherein natural and social phenomena, including the discourses of both, should neither be seen nor studied separately, but treated as hybrids created (and controlled for) through public interaction between people, artifacts and concepts (cf. e.g. Murphy 2010; Dymitrow et al. 2018).

The concept 'hybrid geographies' has been outlined by Whatmore (2002) in her pioneering account of how human agency together with materials, discourses and knowledge create hybrid collectives or "relational being and becoming". As Cloke (2006: 77) put it, such "hybrid approaches seem well capable of rematerializing and even resocializing our cultural understandings of rural [and urban] spaces". In line with the hybrid approach, an array of new concepts such as 'the new rural', 'rurban', 'post-rural', 'suburban', 'periurban', 'exurban' or 'counter-urban' have been launched to redress the fuzziness. Nevertheless, all are still nothing but neologistic variations on the concepts of 'rural' and 'urban'. In order to define 'peri-urban', one still needs to define the 'urban'.

There are multiple criticisms of the use of 'rural/urban' in such expanded (hybrid) forms. Most obviously, they fail to explain 'rural/urban' because of the extreme language of self-referentiality without providing external reference, and could thus be seen as an attempt to resubstantiate an established yet dwindling system of meaning. For example, when examining what goes on in "rural areas", geographers usually depart from a spatial delimitation or an activity delimitation. The problem is that when departing from a spatial delimitation, the focus is on certain material manifestations of rurality (e.g. remoteness, open landscape, or nature), yet the entire variability of the studied area's performances becomes 'rural' by extension, normalizing thus the concept's definition through a morphological contingent. Contrarily, when departing from an activity delimitation, "rural activities" are often identified from a preconceived traditionalist understanding of rurality (e.g. farming, hunting, mining, and so on), whereby any area exhibiting those traits becomes rural by extension, effectively normalizing rurality's definition by the actions of a few. By so doing, geographers will always be able to make any performance or any spatiality 'rural' and the hybridity will eventually be lost ${ }^{8}$.

This phenomenon can be seen in many academic works, e.g. in this recent compilation thesis about growth and decline in "rural Sweden": "In this thesis, rural is operationalized in different ways between Papers II and III. Paper II has a regional view on rural areas since it is interested in the labor market aspects of sparse social structures. In contrast, Paper III applies a local definition of rural whereby all urban localities with a population over 1,000 are classified as urban while the rest of Sweden is classified as rural. [...] In Article I, which looks at employment trajectories for agricultural

\footnotetext{
8 The same logic applies to 'urban' as well, by exchanging prototypical tropes of rurality for 'urban' ones.
} 
workers, rural is not defined explicitly; instead agriculture is looked upon as a rural sector. As the discussion above suggests, this does not mean that agriculture is a defining characteristic of rural, only that agriculture mainly takes place in rural areas" (Hedlund 2017: 6).

Here, the author defines rural areas in three different ways: once regionally, once locally (while placing settlements of 1,000 inhabitants and Stockholm in the same urban basket), and once by not defining them explicitly, yet exchanging it for the agricultural sector (which the author qualifies as not being synonymous with 'rurality', but does so anyway because agriculture takes places in 'rural areas', which are 'rural' because there is agriculture?). Noticeably, the author is interested in three different aspects of economic life: (1) labor market aspects of sparse social structures; (2) socio-economic characteristics of small $(<1,000)$ settlements; and (3) employment trajectories of agricultural workers. These are clear delimitations and there is really no need for involving the rural label. But the label is involved. The main problem, however, is that the results from the three studies are aggregated and repackaged as knowledge how "rural Sweden" is. The thesis' conclusion is namely that "different rural areas have experienced development differently" and that "the heterogeneity of rural areas is a product of both growth and decline" (Hedlund 2017: III). But could this be so simply because rural areas have been defined differently in the first place? ${ }^{9}$

Such proclivity to "[think] critically about rurality but nonetheless thinking about it" (Halfacree 2012) is intellectually treacherous in that it may even instantiate a form of apologetics. Confer, e.g., the following statement: "This article shows that while no single rural/ urban classification can be used for all geographies, using such a product helps to better understand the differing characteristics

\footnotetext{
9 My intention is by no means to 'hang out' this work (or any other work cited) as negligent sui generis. The use of examples is strictly for demonstrative purposes in that it is symptomatic of widespread trends how 'rural/urban' are handled in academic contexts.
}

of rural and urban areas in a consistent, transparent way" (Pateman 2011: 11).

Here, initial denouncement is followed directly by praise: from lack of unity to full consistency (and even transparency?). Moreover, one cannot better understand the characteristics of rural and urban areas unless one first defines what 'rural/urban' is (which, as stated upfront, is insuperably difficult). So by a priori defining 'rural/urban' in order to a posteriori find out what 'rural/urban' is, the horse is put before the cart. Effectively, better understanding here equals to 'you'll get what you want'. This tendency is so strong it even penetrates expressly critical inquiries, as in Woodward (1996: 65), who shows "how discourses of 'the rural' operate to conceal 'deprivation' in rural areas"; in Cloke and Milbourne (1992: 371), who foresee "forays into issues of the cultural constructs of rurality in contemporary rural lifestyles"; or in Edensor (2006), where rural performances are defined as "ways in which people are predisposed to carry out unquestioned and habitual practices in rural settings" [emphases added]. Human geography is awash with similar circular analyses, all leading to the same outcome: loss of hybridity and the retention of 'rural/urban' as traditionally conceived.

\section{'Rural/urban' as relationalities}

While hybrid approaches try to stitch together old concepts because they do not seem to work independently, relational approaches want to make sense of how elements that make up those concepts fit together. As Wylie (2007: 200) put it, "relations do not occur in space, they make spaces - relational spaces, and the geography of the world is comprised of these" (cf. also Massey 2005: 107). Therefore, a relational approach seeks to explore "both the relations that constitute the rural [or urban] and the shifting nature of the relation between the rural and the urban" (Woods 2011: 17). The starting point for relational discussions about 'rural/urban' is that they are spatial concepts, and to make a distinction between them we need to agree 
that they refer to different kinds of space. This raises the question of what is meant by "space" in the first place. As Somerville et al. (2014: 278) conclude, the problem is that "it is usually assumed that 'space' has structure, but there seems to be no general agreement about its exact form" (see also Couclelis 1992).

According to Halfacree (2006: 52) "space" may be interrogated in terms of the extent to which it demonstrates structured coherence, i.e. the overall degree of stability between economy, state and civil society at the local level. To accomplish this, Halfacree (2006) envisions rural space as a tripartite model, where rural localities, representations of the rural and lives of the rural are tightly interwoven: (1) rural localities are inscriptions of relatively distinctive spatial practices linked to production or consumption; (2) representations of the rural are expressions of capitalist interests, bureaucrats and politicians; (3) everyday lives of the rural are fractured notions of individual and social elements in their cognitive interpretation and negotiation ${ }^{10}$. Any aspect of rurality, then, can be mapped onto this model, and when its three facets are examined together, their totality can be said to articulate any of the following forms of rural coherence: (a) congruent and unified; (b) contradictory and disjointed; and (c) chaotic and incoherent. Of these only the first expresses full structured coherence (Somerville et al. 2014: 280). However, due to rapid societal changes, spaces "a" are becoming rarer, while spaces "b" are becoming the norm. Perhaps most worrying are places " $c$ ", which "hold together

10 The division of space into three facets stems from Lefebvre's (1991) work "The production of space", in which the author envisions 'space' as produced by dynamic interrelations between representations of space, representational space and practice over time, by drawing on examples from 'urban' contexts. So while Halfacree's (2006) model, which in turn draws on Lefebvre's work, relates to 'rurality' specifically, on a conceptual level it applies to 'urbanity' as well. Halfacree's model was later modified to eliminate instances of self-referentiality (Dymitrow \& Brauer 2017: 37) and also redeveloped into a more general model of (any) labeled space (Dymitrow 2017b: 131). at neither the perceptual nor conceptual level [...] represent[ing] a potentially subversive alternative within the overall logic of abstract spatiality" (Halfacree 2006: 52). So while structured coherences are always dynamic and fluid (Massey 2005), Halfacree's triad approach gives an approximation of what may be meant when 'rural/urban' is inferred, but perhaps more importantly how coherent that inferral is.

The relational approach with regard to 'rural/urban' has become popular in human geography over the last decades. However, it has also come under criticism. Although useful for its descriptive capabilities to conceptualize reality, it is limited (even impotent) in its predictive capabilities (Nowak 2014). Since relational approaches refuse to state a priori their epistemological, ontological and methodological commitments, their argument suffocates all of the finer intricacies of their object of study (Venturini 2010). Hence, while the relational approach can help rethink the relationship between 'rural' and 'urban', it is perhaps more appropriate for explorative scientific approaches, whereas in policy and planning there is a pressing need to define one's position in advance in order to commence a meaningful intervention (Earl 2002) ${ }^{11}$. While rejecting concepts of space and place as fixed entities and retreating from privileging the social, a relational approach tends to adopt "an agnostic position" (Woods 2011: 40-41). By doing so, it assumes an attitude that is inherently incompatible with the rigid realities of rural/urban opposition. Effectively, a relational approach tacitly accepts 'rural' and 'urban' but instead relativizes their respective individualities. This is a logical contradiction, stemming from the inability to let go of established frameworks with simultaneous realization that they do not

11 Precise and unambiguous language is mandatory in many contexts, including medicine, judiciary systems or air traffic control, where ineffective communication may incur dire consequences, including death. In situations where conceptually induced harm is not sufficiently sensed, laxity is practiced. Expectedly, 'rural' and 'urban' projects abound. 
work in practice. What we are left with then are inconsistent messages and optimistic cliché-like statements, leading to the lack of structured coherence. In other words, we get caught in our own metaphors, sometimes balancing on the verge of incongruity.

\section{'Rural/urban' as performativities}

Accepting the perils of relationality, human geographers have been attending to the relations and experiences "shaped by a focus not on the way the world is, but on how the world is coming to be through an engagement with our interventions in, and responses to, the world" (Greenhough 2010: 42, emphases in original). Mindful that "[s]ocial practices have citational force because of the spaces in which they are embedded" (Thrift 2000: 677), calls have been awoken for new forms of humanism, one "that avoids the rationalist and self-righteous claims of the old ones but maintains elements of the experiential dimension of social life" (Simonsen 2013: 10). With that mindset, geographers have entered a new dimension of knowledge-making, where comprehension of lived experience, agency and participation has become increasingly relevant for how we understand various concepts from a range of theoretical, methodological and empirical considerations (cf. Nelson 1999; Nash 2000; Dewsbury 2000; Houston \& Pulido 2002; Szerszynski et al. 2003; Pearson 2006; Waitt \& Cook 2007; Kay 2012).

Because assertions about urbanization of the countryside (and vice versa) are known to be based on subjective characterizations of 'urban' and 'rural' (Hubbard 2006: 69-70; Woods 2011: 44), they have become "implicated in the production of places and, in particular, in the judgment of people's practices within places" (Cresswell 2009)12. This has

12 This approach in line with Jean Baudrillard's ideas of the age of simulations, "where the map no longer follows on from the territory, seeking to represent it, but instead 'precedes' and 'engenders' it". In this view, "representations of rurality [are] being deployed to shape existing rural spaces, or even to corral assemblages spawned numerous attempts to access the more-than-representational rural and urban geographies (Lorimer 2005; Edensor 2006; Wylie 2007; Carolan 2008) by adding significant performative gravity to those "largely unreflexive habits, quotidian performances that tether people to place" (Edensor 2006: 491). Subsumed under a more general disciplinary refocus on 'bottom-up' (Barnett 2011; Pain 2004), 'outside-in' (Bawaka Country et al. 2016) and 'more-than' (Head 2011) perspectives, this new wave of gaining understanding has been instantiated through numerous attempts to access geographies where "rural [and urban] experiences are felt, sensed, [and] intuited through bodily actions and performances (Woods 2010: 835). Such an approach privileges first-hand stories and provides an alternative to grand narratives that otherwise inform understandings of 'rural/urban', but it also implicitly extends an invitation to the creation of those concepts (e.g., McGill 2000; Edensor 2006; Woods 2010; Bossuet 2013; Kruger 2013; Mordue 2014; Cassel \& Pettersson 2015; Shirley 2015; Laszczkowski 2016; Wright \& Eaton 2018).

Notably, this philosophical insight has also come to implicate geographers as active performers of rurality (Woods 2010) and, by implication, of urbanity (cf. Brenner 2013): "[T]he practice of rural geography is closely tied to the performance of rurality, and rural geographers are revealed not only as observers and recorders of the rural but also as active agents in producing, reproducing and performing rurality" (Woods 2010: 844).

There is a caveat though. While commendable from an ethical point of view, the sheer recognition of one's own role in the process of conceptual enactment alone is unlikely to be effective unless we can pinpoint in what way such enactment creates realities (Brauer \& Dymitrow 2014; Dymitrow \& Brauer 2014). Yet, this particular relation has to date not been scrutinized in an effective way, or fully understood. A number of questions come to mind: (a) how do we identify, approach

of rurality 'beyond' the rural” (Halfacree 2009b: 449). 
and use 'rural/urban'; (b) where exactly do we place those rural/urban performances; and, most importantly, (c) who is really performing rurality/urbanity?

This issue is particularly visible in an analysis of seven papers handpicked by Woods (2010) as a point of embarkation for his seminal paper in Progress in Human Geography about performing rurality, which he characterized to "have critically reflected on the practice and positionality of being a rural researcher". However, a more exhaustive analysis shows that while the authors did address issues of academic integrity (Pini 2004; Edelman 2009), holism (Chacko 2004), novelty of approach (Dougill et al. 2006; Moseley 2007) or ethical considerations (Leyshon 2002; McAreavey 2008), none had really addressed the consequences of their heralded agency "in producing, reproducing and performing rurality" (Woods 2010: 844). Dymitrow and Brauer (2017: 35-36) summarize it as follows:

"Consider the following compilation: desert farming in Mali, luxury sub-London homes, peasant movements in Guatemala, chronic poverty in West Bengal, youth identity in South West England, the sugar cane industry in Australia, and a tourist-packed park fringed by the UK's most urbanized area. What is the common denominator? Is there even any? The Occam's razor answer is that they all contribute to the production of "rural theory". However, such production takes place even though the rural location is unspecified ("rural Africa"), anonymized ("Small Village"), generalized ("sugar cane industry") or synergized ("reflections of past research"), but also when the rural label is pre-given by an organization or by a research project, or simply arrived at by implication be it by lack of update at best (the false equivalency farming $=$ rural), or by lack of reflection at worst (stereotyping)".

In other words, while all authors expressly signaled their awareness of partiality and positionality in connection to the whereabouts of "rural knowledge", they at the same time evinced a sleight of hand, which Hara- way (1991: 189) has described as the "god trick": representation while escaping representation.

\section{'Rural/urban' as networks}

To escape the trap of relativism, a more apprehendable view borne out of the relational tradition is that of networks. Emphasizing "the significance of networks, connections, flows and mobilities in constituting space and place, and the social, economic, cultural and political forms and processes associated with them" (Woods 2011: 40) has helped highlight the complexity of rural/urban constructions. Networks, in this sense, signify an interconnected or interrelated chain, group or system (cf. Hägerstrand 1953), and usually refer to the final product that exerts impact or influence over something. Understanding 'rural/ urban' as complex assemblages of material, social and human actors aligns with actornetwork theory (ANT) (Latour 2005) ${ }^{13}$.

ANT is a constructionist approach to social theory which refrains from essentialist explanations of various social phenomena. Looking into how social processes are being stabilized (Latour 2005) through relations which are both material (between things) and semiotic (between concepts), ANT's application has proven important to map out networks that maintain certain ways of thinking in society (other than just "relationize" them) (cf. Manning 2002; Rutland \& Aylett 2008; Young et al. 2010). ANT, however, comes with its own set of problems. The biggest concerns its treatment of inanimate objects as actors, a view that clashes with the concept of intentionality (Winner 1993). It has also been criticized for its amorality (Shapiro 1997), lack of criticism and failure to challenge structures of domination (Whittle \& Spicer 2008), as well as for

13 Unlike purely social networks inherent of Hägerstrand's (1953) diffusion of innovations theory, ANT is a much broader approach that also involves technologies, research evidence, financial resources, institutions, regulations, weather conditions, physical barriers, animals and the like (cf. Brauer 2012; Brauer \& Dymitrow 2017). 
being too descriptive to virtually explain any social process (Amsterdamska 1990). Hence, its mode of sociology runs the risk of debauching into endless chains of association.

Acknowledging this critique, Dymitrow and Brauer (2018) develop the network model in the context of 'rural/urban' concept retention, by adopting a pragmatic approach. Their work sets out to make sense of a simple yet intriguingly under-researched problem: If we, as geographers, know 'rural/ urban' to be spatial concepts of poor analytical and explanatory merit, why do we keep resorting to them so often, with the imminent risk of compromising communication and corroding social theory? By drawing extensively on theoretical frameworks from previous literature, they pursue a structured case against unsolicited/unreflexive uses of 'rural/ urban' in human geography. By making use of the concept extra-scientific factor (Weber 1904 [1941]; Fleck 1935 [1979], Kuhn 1962 [1970]), the authors unravel a dozen psychosocial factors influencing retention of 'rural/ urban' in human geography (boundary-work, perspectivism, politicized inclusionism, innovation requirement, cognitive dissonance, confirmation bias, analytical ethnocentrism, dualistic thinking, textual entrapment, routinization, vested interest, imperception of concept-subject relation). More importantly, the authors do not end there; instead, they propose a defiltration maxim - a set of questions we as geographers can ask ourselves to identify extra-scientific factors likely to retain 'rural/urban' within our personal sphere (Dymitrow \& Brauer 2018: 211). Such a move goes beyond conventional ANT in that it not only maps the networks but also delves into the nooks of 'human nature', while at the same time trying to sort out our own positionalities in the process of undesirable concept retention.

\section{Conclusion}

Due to the immense societal changes, the rural/urban distinction has long been criticized by researchers and professionals for its lack of analytical and explanatory power in a relational, interconnected world that defies simple categorizations. The concepts 'rural' and 'urban', so it seems, are often used without careful consideration of what is really implied. What we do know is that changing patterns of land use, modes of connectivity, livelihoods, lifestyles, and spatial relations alter our society, making it in constant flux. We also know that 'rural' and 'urban' have been subject to immense theoretical and philosophical repositionings. They have been envisioned as binaries, dichotomies, dualisms, continua and sliders; theorized as phenomena, forces and social constructs; envisioned as structured coherences or chaotic conceptions, as rhetorical devices or ideologies, as categories of thought or conversational realities, as narratives or exclusionary othering devices. Researchers have tried to understand 'rural/urban' through philosophical recourses to 'embodiment', 'morethan-human'-approaches, 'assemblages', 'effacement', 'post'- and 'beyond'-perspectives, and a host of other transdisciplinary criss-crossings. All, in one way or another, have proven treacherous, ambiguous or contentious.

Realizing that conceptual tropes can solidify understandings of abstract psychologies (Ramakrishnan 2014), ways in which they lend insight into complex social relations and identities is an important part of how the concepts 'rural' and 'urban' need to be approached in the face of the current state of affairs (cf. Bell 1992). In other words, it is imperative to firstly and foremost change our relationship with 'rural/urban', regardless of whether we see them as materially definable spaces, as academically titillating spaces of representation or as local sources of knowledge that deserve elevation to a position of authority. Contrarily, given all we know about 'rural/ urban' today should take us in the direction of viewing them as communicatively weary approximates and perhaps abort feeding the constant cyclical processes of rural/urban conceptual sanitation. 
This focal reshuffle could be summarized in three under-researched "human" dimensions of 'rural/urban': conceptual constitution (what do we put into these concepts?), performativity (how do we keep the concepts alive?) and implications (what are the negative effects of sustaining the concepts?). However, unlike previous attempts that targeted these dimensions mostly through a focus on semantics, reflexivity and misinterpretations, greater emphasis need to be put on the production of rural/urban knowledge from the position of the researcher. This implies paying greater attention to how concepts operate at a cognitive level, how they gain foothold and are collectively maintained, and how to avoid harm by "unlearning" bad concepts.

Human geography has changed, expanded. Being a geographer today means being trained and capable of doing many kinds of research, none of which must revolve around vestigial spatial concepts just because

\section{References}

Amsterdamska O., 1990. Book review: Surely you're joking, Mr Latour!. Science, Technology and Human Values, vol. 15, no. 4, pp. 495-504.

BAILEY W.L., 1924. The shifting bases of rural sociology. Publications of the American Sociological Society, vol. 19, pp. 161-164.

Barnett C., 2011. Geography and ethics: Justice unbound. Progress in Human Geography, vol. 35 , no. 2 , pp. 246-255.

Baron S., Dougherty T., Miller K., 2015. Why is there female under-representation among philosophy majors? Ergo: An Open Access Journal of Philosophy, vol. 2, no. 14, pp. 329-365.

Bawaka Country, Wright S., Suchet-Pearson S., Lloyd K., Burarrwanga L., Ganambarr R., Maymuru D., Sweeney J., 2016. Co-becoming Bawaka: Towards a relational understanding of place/space. Progress in Human Geography, vol. 40, no. 4, pp. 455-475. they continue to be tolerated (cf. Dymitrow \& Brauer 2018). And while everything is certainly located in "space", if we keep elevating its role by means of problematic concepts, we instead churn up a rural/urban thanatophobia that is never likely to retire. If understanding the world is changing it (Gibson-Graham \& Roelvink 2010: 342), thinking about change in new ways must involve questioning the assumptions underlying formal practices that shape contemporary societal organization. To break away from the grip of 'rural/ urban' we need to - in Holder's (2008: 249) words - be "prepared to think the impossible [...] or rather without more or less canonical tables of values".

Editors' note:

Unless otherwise stated, the sources of tables and figures are the authors', on the basis of their own research.

Bealer R.C., Willits F.K., Kuvlesky W.P., 1965. The meaning of rurality in American society: Some implications of alternative definitions. Rural Sociology, vol. 30, no. 3, pp. 255-266.

BELL M.M., 1992. The fruit of difference: The ruralurban continuum as a system of identity. Rural Sociology, vol. 57, no. 1, pp. 65-82.

Berger P.L., LuCKMann T., 1966. The social construction of reality: A treatise in the sociology of knowledge. Garden City: Anchor Books.

Berman M., 1983. All that is solid melts into air: The experience of modernity. London: Verso.

Bohleber W., Fonagy P., Jiménez J.P., SCARfone D., VARVIN S., ZYSMAN S., 2013. Towards a better use of psychoanalytic concepts: A model illustrated using the concept of enactment. The International Journal of Psychoanalysis, vol. 94, no. 3, pp. 501-530.

Bossuet L., 2013. Les ruralités du quotidien ou de nouvelles alliances. Géographie, Économie, Société, vol. 15, no. 1, pp. 47-65. 
Bosworth G., SOMERVILle P. (eds.), 2014. Interpreting rurality: Multidisciplinary approaches. London-New York: Routledge.

Brauer R., 2012. Synthesizing Time Geography and Actor-Network Theory: An ontological discussion combining Time Geography and ActorNetwork Theory concepts with regard to telepresence. Gothenburg: University of Gothenburg.

Brauer R., Dymitrow M., 2014. Quality of life in rural areas: A topic for the rural development policy? Bulletin of Geography. Socio-economic Series, vol. 25, pp. 25-54.

Brauer R., Dymitrow M., 2017. Human Geography and the hinterland: The case of Torsten Hägerstrand's 'belated' recognition. Moravian Geographical Reports, vol. 25, no. 2, pp. 74-84.

BrenNer N., 2011. The urbanization question, or, the field formerly known as urban studies (lecture). Harvard: Graduate School of Design, Harvard University (1 November 2011).

Brenner N., 2013. Theses on urbanization. Public Culture, vol. 25, no. 1, pp. 85-114.

BrenNer N., 2015. The urban age in question: Towards a new epistemology of the urban (lecture). Melbourne: Melbourne School of Design (17 March 2015).

Brenner N., Theodore N., 2002. Cities and the geographies of "actually existing neoliberalism". Antipode, vol. 34, no. 3, pp. 349-379.

Buss D., 2015. Evolutionary psychology: The new science of the mind. New York: Routledge.

Carolan M.S., 2008. More-than-representational knowledge/s of the countryside: How we think as bodies. Sociologia Ruralis, vol. 48, no. 4, pp. 408-422.

Cassel S.H., Petterson K., 2015. Performing gender and rurality in Swedish farm tourism. Scandinavian Journal of Hospitality and Tourism, vol. 15, no. 1-2, pp. 138-151.

CHACKO E., 2004. Positionality and praxis: Fieldwork experiences in rural India. Singapore Journal of Tropical Geography, vol. 25, no. 1, pp. 51-63.

Champion A., Hugo G., 2004. New forms of urbanization: Beyond the urban-rural dichotomy. Hants, UK: Asghate.

CLOKE P.J., 1977. An index of rurality for England and Wales. Regional Studies, vol. 11, no. 1, pp. 31-46.
Cloke P., 2006. Conceptualizing rurality [in:] P. Cloke, T. Marsden, P.H. Mooney (eds.), Handbook of rural studies, London: Sage, pp. 18-28.

Cloke P., Johnston R., 2005a. Deconstructing human geography's binaries [in:] P. Cloke, R. Johnston (eds.), Spaces of geographical thought: Deconstructing human geography's binaries, London: Sage, pp. 1-20.

Cloke P., Johnston R. (eds.), 2005b. Spaces of geographical thought: Deconstructing human geography's binaries, London: Sage.

Cloke P., Milbourne P., 1992. Deprivation and lifestyles in rural Wales - II. Rurality and the cultural dimension. Journal of Rural Studies, vol. 8, no. 4, pp. 359-371.

ColBY C.C., 1933. Centrifugal and centripetal forces in urban geography. Annals of the Association of American Geographers, vol. 23, no. 1, pp. 1-20.

Copp H.H., 1972. Rural sociology and rural development. Rural Sociology, vol. 37, no. 4, pp. 515-533.

Couclelis H., 1992. Location, place, region, and space [in:] R.F. Abler, M.G. Marcus, J.M. Olson (eds.), Geography's inner worlds, New Brunswick: Rutgers University Press, pp. 215-233.

Cresswell T., 2009. Discourse [in:] R. Kitchin, N. Thrift (eds.), International encyclopedia of human geography, London: Elsevier, pp. 211-214.

Dahly D.L., AdaIR L.S., 2007. Quantifying the urban environment: A scale measure of urbanicity outperforms the urban-rural dichotomy. Social Science \& Medicine, vol. 64, no. 7, pp. 1407-1419.

DerRIDA J., 1981. Positions. Chicago: University of Chicago Press.

DEWEY R., 1960. The rural-urban continuum: Real but relatively unimportant. American Journal of Sociology, vol. 66, no. 1, pp. 60-66.

DewsBuRY J.-D., 2000. Performativity and the event: Enacting a philosophy of difference. Environment and Planning D: Society and Space, vol. 18, no. 4, pp. 473-496.

Dijkstra L., Garcilazo E., McCann P., 2013. The economic performance of European cities and city regions: Myths and realities. European Planning Studies, vol. 21, no. 3, pp. 334-354. 
Dougill A.J., Fraser E.D.G., Holden J., Hubacek K., Prell C., Reed M.S., Stagl S., Strnger L.C., 2006. Learning from doing participatory rural research: Lessons from the Peak District National Park. Journal of Agricultural Economics, vol. 57, no. 2, pp. 259-275.

Dymitrow M., 2013. Degraded towns in Poland as cultural heritage. International Journal of Heritage Studies, vol. 19, no. 7, pp. 613-631.

Dymitrow M., 2014. The effigy of urbanity or a rural parody?. Journal of Cultural Geography, vol. 31, no. 1, pp. 1-31.

Dymitrow M., 2017a. Degradation, restitution and the elusive culture of rural-urban thinking. Fennia - International Journal of Geography, vol. 195, no. 1, pp. 36-60.

Dymitrow M., 2017b. Rural/urban redux. Conceptual problems and material effects. Gothenburg: University of Gothenburg.

Dymitrow M., Biegańska J., Grzelak-KostulsKA E., 2018. Deprivation and the rural-urban trap. Tijdschrift voor economische en sociale geografie, vol. 109, no. 1, pp. 87-108.

Dymitrow M., Brauer R., 2014. Social deprivation and urbanity as the elephant in the room [in:] R. Efe, T.T. Onay, I. Sharuho, E. Atasoy (eds.), Urban and urbanization, Sofia: St. Kliment Ohridski University Press, pp. 381-395.

Dymitrow M., Brauer R., 2017. Performing rurality. But who? Bulletin of Geography. Socio-economic Series, vol. 38, pp. 27-45.

Dymitrow M., Brauer R., 2018. Meaningful yet useless? Factors behind the retention of questionable concepts in human geography. Geografiska Annaler: Series B, Human Geography, vol. 100, no. 3, pp. 195-219.

Dymitrow M., Halfacree K., 2018. Sustainability-differently. Bulletin of Geography. Socioeconomic Series, vol. 40, pp. 7-16.

Dymitrow M., StenseKe M., 2016. Rural-urban blurring and the subjectivity within. Rural Landscapes: Society, Environment, History, vol. 3, no. 1, pp. 1-13.

EARL D., 2002. A defense of the classical view of concepts. Denver: University of Colorado.

EASterlin R.A., Angelescu L., ZWEIg J.S., 2011. The impact of modern economic growth on urbanrural differences in subjective well-being. World Development, vol. 39, no. 12, pp. 2187-2198.
Edelman M., 2009. Synergies and tensions between rural social movements and professional researchers. Journal of Peasant Studies, vol. 36, no. 1, pp. 245-265.

EDENSOR T., 2006. Performing rurality [in:] P. Cloke, T. Marsden, P.H. Mooney (eds.), Handbook of rural studies, London: Sage, pp. 484-495.

ERIKSSON M., 2010. "People in Stockholm are smarter than countryside folks" - Reproducing urban and rural imaginaries in film and life. Journal of Rural Studies, vol. 26, no. 2, pp. 95-104.

Falk W.W., Pinhey T.K., 1978. Making sense of the concept rural and doing rural sociology: An interpretive perspective. Rural Sociology, vol. 43, no. 4, pp. 547-558.

FLECK L., 1935 [1979]. Genesis and development of a scientific fact. Chicago: University of Chicago Press.

Freibach-Heifetz D., Stopler G., 2008. On conceptual dichotomies and social oppression. Philosophy \& Social Criticism, vol. 34, no. 5, pp. 515-535.

GALJART B., 1973. The future of rural sociology. Sociologia Ruralis, vol. 13, no. 3-4, pp. 254-263.

GalpIN C.J., 1918. Rural life. New York: Century.

Galpin C.J., CampBell W.J., Vogt P.L., 1918. Rural sociology: Standardization of research. The American Journal of Sociology, vol. 24, no. 3, pp. 303-310.

Gibson-Graham J.K., 2000. Poststructural interventions [in:] E. Sheppard, T. Barnes (eds.), A companion to economic geography, Oxford: Blackwell, pp. 95-110.

Gibson-Graham J.K., Roelvink G., 2010. An economic ethics for the Anthropocene [in:] N. Castree, P.A. Chatterton, N. Heynen, W. Larner, M.W. Wright (eds.), The point is to change it: Geographies of hope and survival in an age of crisis, Oxford: Wiley-Blackwell, pp. 320-346.

GIERYN T.F., 1983. Boundary-work and the demarcation of science from non-science: Strains and interests in professional ideologies of scientists. American Sociological Review, vol. 46, no. 6, pp. 781-795.

Gillette J.M., 1917. The scope and methods of instruction in rural sociology. Publications of the American Sociological Society, vol. 11, pp. 163-180. 
Greenhough B., 2010. Vitalist geographies: Life and the more-than-human [in:] B. Anderson, P. Harrison (eds.), Taking-place: Non-representational theories and geography, London: Routledge, pp. 37-54.

GuBA E.G., LINCOLN Y.S., 1994. Competing paradigms in qualitative research [in:] N.K. Denzin, Y.S. Lincoln (eds.), The Sage handbook of qualitative research, Thousand Oaks: Sage, pp. 105-117.

HäGERSTRAND T., 1953. Innovation diffusion as a spatial process. Chicago: University Press.

HALFACREE K., 1993. Locality and social representation: Space, discourse and alternative definitions of the rural. Journal of Rural Studies, vol. 9, no. 1, pp. 23-37.

Halfacree K., 2006. Rural space: Constructing a three-fold architecture [in:] P. Cloke, T. Marsden, P.H. Mooney (eds.), Handbook of rural studies. London: Sage, pp. 44-62.

HalfaCREE K., 2009a. Urban-rural continuum [in:] R. Kitchin., N. Thrift (eds.), International encyclopedia of human geography, London: Elsevier, pp. 119-124.

HalfaCree K., 2009b. Rurality and post-rurality [in:] R. Kitchin, N. Thrift (eds.), International encyclopedia of human geography, London: Elsevier, pp. 449-456.

Halfacree K., 2012. Diverse ruralities in the 21st century: From effacement to re-invention [in:] L.J. Kulcsár, K.J. Curtis (eds.), International handbook of rural demography, Dordrecht: Springer, pp. 387-400.

HaLL T., 1998. Urban geography. London: Routledge.

HANSEN K.P., 2011. Kultur und Kulturwissenschaft. Tübingen: A. Francke Verlag UTB.

HaraWAY D., 1991. Simians, cyborgs, and women: The reinvention of nature. London: Free Association Books.

HeAD L., 2011. More than human, more than nature: Plunging into the river. Griffith Review, vol. 31, pp. 37-43

Hedlund M., 2017. Growth and decline in rural Sweden: Geographical distribution of employment and population 1960-2010. Umeå: Umeå University.

Hoggart K., 1990. Let's do away with rural. Journal of Rural Studies, vol. 6, no. 3, pp. 245-257.

HOLDER R.W., 2008. Oxford dictionary of euphemisms. Oxford: Oxford University Press.
Houston D., Pulido L., 2002. The work of performativity: Staging social justice at the University of Southern California. Environment and Planning D: Society and Space, vol. 20, no. 4, pp. 401-424.

Hubbard P., 2006. City. Abingdon-New York: Routledge.

Jonas A.E.G., McCann E., Thomas M., 2015. Urban geography. A critical introduction. Oxford: Wiley-Blackwell.

KAY R., 2012. Managing everyday (in)securities: Normative values, emotional security and symbolic recognition in the lives of Russian rural elders. Journal of Rural Studies, vol. 28, no. 2, pp. 63-71.

Killermann S., 2013. The social justice advocate's handbook: A guide to gender. Austin: Impetus Books.

KIRK W., 1980. The rural-urban continuum: Perception and reality [in:] G. Enyedi, J. Mészáros (eds.), Development of settlement systems, Budapest: Akademiai Kiado, pp. 11-19.

KRUGer L., 2013. Performing urbanity: City drama on street and stage [in:] L. Kruger (ed.), Imagining the edgy city: Writing, performing, and building Johannesburg, Oxford: Oxford University Press, pp. 46-55.

KRZYSZTOFIK R., 2016. Revisiting the question of centripetal and centrifugal forces in urban systems. Geographia Polonica, vol. 89, no. 4, pp. 429-442.

Krzysztofik R., Dymitrow M., Kantor-Pietraga I., SPÓRNA T., 2016. The concept of urban hibernation. European Planning Studies, vol. 24, no. 2, pp. 316-343.

Krzysztofik R., Dymitrow M., Biegańska J., Senetra A., Gavrillidou E., Nadolu B., KantorPietraga I., Grzelak-Kostulska E., Ourellidou E., Luches D., Spórna T., Teodorescu D., Wasilewicz-PszczóŁKoWsKa M., Holmertz G., Szczepańska A., Brauer R., 2017. Landscapes with different logics: A physicalist approach to semantic conflicts in spatial planning. Quaestiones Geographicae, vol. 36, no. 4, pp. 29-45.

KuHN T.S., 1962 [1970]. The structure of scientific revolutions. Chicago: University of Chicago Press. 
LASZCZKOWSKI M., 2016. Performing urbanity: Migrants, the city and collective identification [in:] M. Laszczkowski (ed.), 'City of the future': Built space, modernity and urban change in Astana, New York-Oxford: Berghahn Books, pp. 57-79.

LATOUR B., 1993. We have never been modern. Cambridge: Harvard University Press.

LATOUR B., 2005. Reassembling the social: An introduction to Actor-Network-Theory. Oxford: Oxford University Press.

LefEBVRE H., 1962 [2011]. Introduction to modernity: Twelve preludes, September 1959-May 1961. London-New York: Verso.

LefEBVRE H., 1991. The production of space. Oxford: Blackwell.

Lerner A.M., Eakin H., 2011. An obsolete dichotomy? Rethinking the rural-urban interface in terms of food security and production in the Global South. The Geographical Journal, vol. 177, no. 4, pp. 311-320.

LEYSHON M., 2002. On being 'in the field': Practice, progress and problems in research with young people in rural areas. Journal of Rural Studies, vol. 18, no. 2, pp. 179-191.

LITTLE J., 1999. Otherness, representation and the cultural construction of rurality. Progress in Human Geography, vol. 23, no. 3, pp. 437-442.

LORIMER H., 2005. Cultural geography: The busyness of being 'more-than-representational'. Progress in Human Geography, vol. 29, no. 1, pp. 83-94.

MANNING N., 2002. Actor networks, policy networks and personality disorder. Sociology of Health \& Illness, vol. 24, no. 5, pp. 644-666.

Margolis E., Laurence S. (eds.), 1999. Concepts: Core readings. Cambridge: MIT Press

MASSEY D., 2005. For space. Thousand Oaks: Sage.

MAXWELL J.A., 2012. Qualitative research design: An interactive approach. London: Sage.

McAreavey R., 2008. Researcher and employee: Reflections on reflective practice in rural development research. Sociologia Ruralis, vol. 48, no. 4, pp. 389-407.

McGILL R., 2000. Performing rurality: Tourists and topology in Alice Munro's "Something I've been meaning to tell you" [in:] A. Cabral, R.L. Maia (eds.), Postmodern productions: Text-power-knowledge, Erlangen: Erlangen University, pp. 278-279.
Meeus S.J., Gulinck H., 2008. Semi-urban areas in landscape research: A review. Living Reviews in Landscape Research, vol. 2, no. 3, pp. 1-45.

Milllward H., Harrington L., Ilbery B., BeesLEY K.B., 2003. Milieux, viewpoints, and processes of change in the new countryside [in:] K.B. Beesley, H. Millward, B. Ilbery, B., L. Harrington (eds.), The new countryside: Geographic perspectives on rural change, Brandon-Halifax: Brandon University-Saint Mary's University, pp. 9-23.

Mordue T., 2014. Performing the rural through game-angling [in:] E. Kasbov (ed.), Rural cooperation in Europe: In search of the 'relational rurals', London: Palgrave Macmillan, pp. 121-134.

MORMONT M., 1990. Who is rural? Or how to be rural: Towards a sociology of the rural [in:] T. Marsden, P. Lowe, S. Whatmore (eds.), Rural restructuring, London: David Fulton, pp. 21-44.

Moseley W.G., 2007. Collaborating in the field, working for change: Reflecting on partnerships between academics, development organizations and rural communities in Africa. Singapore Journal of Tropical Geography, vol. 28, no. 3, pp. 334-347.

MuRPHY K., 2010. Fears and fantasies: Modernity, gender and the rural-urban divide. Bern: Peter Lang.

NASH C., 2000. Performativity in practice: Some recent work in cultural geography. Progress in Human Geography, vol. 24, no. 4, pp. 653-664.

NeLSON L., 1999. Bodies (and spaces) do matter: The limits of performativity. Gender, Place and Culture, vol. 6, no. 4, pp. 331-353.

NewBY H., 1986. Locality and rurality: The restructuring of rural social relations. Regional Studies, vol. 20, no. 3, pp. 209-215.

NiLsSON B., LundGREN A.S., 2015. Logics of rurality: Political rhetoric about the Swedish North. Journal of Rural Studies, vol. 37, pp. 85-95.

NowaK A.W., 2014. Ontological imagination and phronetic social science. STS and a quest for just society [in:] S. Malou Strandvad, K. Dupret (eds.), Proceedings of the DASTS 2014 Conference "Enacting Futures" (12-13 June), Roskilde: Danish Association for Science and Technology Studies, p. 35 
Özgen E., 2004. Language, learning, and color perception. Current Directions in Psychological Science, vol. 13, no. 3, pp. 95-98.

PAHL R., 1966. The rural-urban continuum. Sociologia Ruralis, vol. 6, no. 3, pp. 299-329.

PAIN R., 2004. Social geography: Participatory research. Progress in Human Geography, vol. 28, no. 5, pp. 652-663.

Pateman T., 2011. Rural and urban areas: Comparing lives using rural/urban classifications. Regional Trends, vol. 43, no. 1, pp. 11-86.

Pearson M., 2006. In comes 1: Performance, memory and landscape. Exeter: University of Exeter Press.

PILE S., 1994. Masculinism, the use of dualistic epistemologies and third space. Antipode, vol. 26, no. 3, pp. 255-277

PILE S., 1999. What is a city? [in:] D. Massey, J. Allen, S. Pile (eds.), City worlds, London-New York: Routledge, pp. 3-50.

PINI B., 2004. On being a nice country girl and an academic feminist: Using reflexivity in rural social research. Journal of Rural Studies, vol. 20, no. 2, pp. 169-179.

Rabilnge R., van Diepen C.A., 2000. Changes in agriculture and land use in Europe. European Journal of Agronomy, vol. 13, no. 2, pp. 85-99.

RAMAKRISHAN K., 2014. Disrupted futures: Unpacking metaphors of marginalization in eviction and resettlement narratives. Antipode, vol. 46, no. 3, pp. 754-772.

ReY G., 1983. Concepts and stereotypes. Cognition, vol. 15, no. 1, pp. 237-262.

RUSTA A., 2018. Deconstruction of rural-urban divide in new tools prospective. Mediterranean Journal of Social Sciences, vol. 9, no. 5, pp. 157-163.

RutLAnd T., AyletT A., 2008. The work of policy: Actor networks, governmentality, and local action on climate change in Portland, Oregon. Environment and Planning D: Society and Space, vol. 26, no. 4, pp. 627-646.

Scott A., Gilbert A., Gelan A., 2007. The urbanrural divide? Myth or reality? Aberdeen: Macaulay Institute.

SHAPIRO S., 1997. Caught in a web: The implications of ecology for radical symmetry in STS. Social Epistemology, vol. 11, no. 1, pp. 97-110.
SHER J.P., 1977. Pluralism and the countryside: A brief profile of rural America [in:] J.P. Sher (ed.), Education in rural America, Boulder: Westview Press, pp. 1-8.

SHIRLEY R., 2015. Rural modernity, everyday life and visual cultures. Farnham: Ashgate.

Sil R., Katzenstein P.J., 2010. Analytic eclecticism in the study of world politics: Reconfiguring problems and mechanisms across research traditions. Perspectives on Politics, vol. 8, no. 2, pp. 411-431.

SIMONSEN K., 2013. In quest of a new humanism: Embodiment, experience and phenomenology as critical geography. Progress in Human Geography, vol. 37, no. 1, pp. 10-26.

SiWALE J., 2014. Challenging Western perceptions: A case study of rural Zambia [in:] G. Bosworth, P. Somerville (eds.), Interpreting rurality: Multidisciplinary approaches, London-New York: Routledge, pp. 15-31.

SOKOŁOWSKI D., 1999. Zróżnicowanie zbioru małych miast i większych osiedli wiejskich w Polsce w ujęciu koncepcji kontinuum wiejsko-miejskiego. Toruń: UMK.

SoKOŁOWSKI D., 2015. Functional differentiation of degraded and restituted towns to the background of other similarly sized towns and villages in Eastern Poland [in:] R. Krzysztofik, M. Dymitrow (eds.), Degraded and restituted towns in Poland: Origins, development, problems, Gothenburg: University of Gothenburg, pp. 249-271.

Somerville P., Halfacree K., Bosworth G., 2014. Conclusion: Interrogating rural coherence [in:] G. Bosworth, P. Somerville (eds.), Interpreting rurality: Multidisciplinary approaches, LondonNew York: Routledge, pp. 278-296.

Stanny M., Ślıwowska Z., Hoffmann R., 2017. Miasto-wies: dychotomia czy continuum? Rozważania osadzone w trzech kontekstach: socjologicznym, ekonomicznym i geograficznym. Zeszyty Naukowe Wydziału Nauk Ekonomicznych, vol. 1, no. 20, pp. 265-279.

StenBACKA S., 2011. Othering the rural: About the construction of rural masculinities and the unspoken urban hegemonic ideal in Swedish media. Journal of Rural Studies, vol. 27, no. 3, pp. 235-244.

SteWART JR C.T., 1958. The urban-rural dichotomy: Concepts and uses. American Journal of Sociology, vol. 64, no. 2, pp. 152-158. 
Szerszynski B., Heim W., Waterton C. (eds.), 2003. Nature performed: Environment, culture and performance. Hoboken: Blackwell.

Thrift N., 1993. An urban impasse?. Theory, Culture and Society, vol. 10, no. 2, pp. 229-238.

Thrift N., 2000. Performing cultures in the new economy. Annals of the Association of American Geographers, vol. 90, no. 4, pp. 674-692.

THRIFT N., 2007. Non-representational theory: Space, politics, affect. London: Routledge.

TönNIES F., 1887 [1957]. Community and society. Mineola: Dover Publications.

Torre A., Wallet F., 2014. Towards new paths for regional and territorial development in rural areas. European Planning Studies, vol. 23, no. 4, pp. 650-677.

TRIBE J., LIBURD J.J., 2016. The tourism knowledge system. Annals of Tourism Research, vol. 57, pp. 44-61.

TUnSTRÖM M., SMAS L., 2017. Spänningar på ett fält - stadsplaneringens diskurs och praktik på gränsen mellan innerstad och förort. Ymer, vol. 137, pp. 145-164.

Ulied A., Biosca O., Rodrigo R., 2010. Urban and rural narratives and spatial development trends in Europe. Barcelona: Mcrit.

VenturINI T., 2010. Diving in magma: How to explore controversies with actor-network theory. Public Understanding of Science, vol. 19, no. 3, pp. 258-273.

WaltT G., Cook L., 2007. Leaving nothing but ripples on the water: Performing ecotourism natures. Social \& Cultural Geography, vol. 8, no. 4, pp. 535-550.

Ward N., BRown D.L., 2009. Placing the rural in regional development. Regional Studies, vol. 43, no. 10, pp. 1237-1244.

Weber M., 1904 [1941]. The "objectivity" of sociological and socio-political knowledge. Tübingen: Mohr.
Whatmore S., 2002. Hybrid geographies: Natures, cultures, spaces. London: Sage.

Whittle A., Spicer A., 2008. Is Actor Network Theory critique?. Organization Studies, vol. 29, no. 4, pp. 611-629.

WINNER L., 1993. Upon opening the black box and finding it empty: Social constructivism and the philosophy of technology. Science, Technology, \& Human Values, vol. 18, no. 3, pp. 362-378.

WIRTH L., 1938. Urbanism as a way of life. American Journal of Sociology, vol. 44, no. 1, pp. 1-24.

Woods M., 2010. Performing rurality and practising rural geography. Progress in Human Geography, vol. 34, no. 6, pp. 835-846.

Woods M., 2011. Rural. New York: Routledge.

Woodward R., 1996. "Deprivation" and "the rural": An investigation into contradictory discourses. Journal of Rural Studies, vol. 12, no. 1, pp. 55-67.

Wright W., EATON W.M., 2018. Representing rurality: Cider mills and agritourism [in:] S.L. Slocum, C. Kline, C.T. Cavaliere (eds.), Craft beverages and tourism, Volume 2: Environmental, societal and marketing implications, Cham: Palgrave Macmillan, pp. 65-82.

WYLIE J., 2007. Landscape. New York: Routledge.

Xin S., Tribe J., Chambers D., 2013. Conceptual research in tourism. Annals of Tourism Research, vol. 41, pp. 66-88.

YeO J.H., Neo H., 2010. Monkey business: Human-animal conflicts in urban Singapore. Social \& Cultural Geography, vol. 11, no. 7, pp. 681-699.

Young D., Borland R., Coghill K., 2010. An ActorNetwork Theory analysis of policy innovation for smoke-free places: Understanding change in complex systems. American Journal of Public Health, vol. 100, no. 7, pp. 1208-1217. 
